\title{
Analisis Tantangan dan Peluang Era Disrupsi bagi Civitas Akademika Universitas Ibn Khaldun Bogor
}

\author{
Bahar, Nur Khofifah Saadiah \\ Universitas Ibn Khaldun Bogor \\ baharunda1@gmail.com,nurkhofifahsaadiah23@gmail.com
}

\begin{abstract}
In today's era, there have been many significant changes. These changes also occur due to something entering a country brought by a foreign country. This incoming change can be through a phenomenon known as globalization. With this phenomenon, it can change the order of life in a country, one of which has an impact on the campus structure. Globalization makes it easy for foreign cultures to enter the country. With the influx of foreigners, let alone modern culture with technology, this is a sophisticated challenge for the country itself. This era is called the era of disruption. Researchers have conducted research to examine this problem. Researchers conducted research with qualitative methods by conducting interviews with selected respondents consisting of students and lecturers from Ibn Khaldun University, Bogor. The results of this study prove that the era of disruption has a major influence in the world which creates several challenges and opportunities that greatly affect the progress of the campus itself.
\end{abstract}

\section{Keywords: disruption era, campus, technology}

\section{ABSTRAK}

Di era sekarang ini, banyak terjadi perubahan-perubahan yang terjadi secara signifikan. Perubahan tersebut terjaid juga akibat adanya sesuatu yang masuk dalam suatu negara yang dibawa oleh negara asing. Perubahan yang masuk ini bisa melalui suatu fenonema yang disebut sebagai globalisasi. Dengan adanya fenomena ini, ini dapat merubah tatanan kehidupan dalam suatu negara, salah satunya berdampak pula pada tatanan kampus. Globalisasi mengenalkan mudahnya budaya asing masuk ke dalam negeri. Dengan masuknya asing tersebut, apalagi budaya modern yang diimbangi dengan canggihnya teknologi, maka ini menjadi sebuah tantangan bagi negara itu sendiri. Era ini disebut dengan era disrupsi. Peneliti telah melakukan sebuah penelitian untuk mengkaji masalah ini. Peneliti melakukan penelitian dengan metode kualitatif dengan melakukan wawancara kepada responden terpilih yang terdiri dari mahasiswa dan dosen dari Universitas Ibn Khaldun Bogor. Hasil dari penelitian ini membuktikan bahwa era disrupsi memiliki pengaruh besar dalam dunia kampus yang membuat adanya beberapa tantangan dan peluang sehingga sangat mempengaruhi kemajuan kampus itu sendiri.

Kata kunci: era disrupsi; kampus; teknologi 


\section{VISA: Journal of Visions and Ideas}

\section{Vol 2 No 2 (2022) 191-201 E-ISSN 2809-2058 P-ISSN 2809-2643 \\ DOI: 47467/visa.v2i2.993}

\section{PENDAHULUAN}

Globalisasi merupakan era dimana kebudayaan asing dengan bebas masuk ke dalam negara manapun di seluruh dunia. Tidak adanya batasan dalam masuknya budaya asing ke dalam negeri membuat tantangan di Indonesia semakin bervariasi. Kata globalisasi sendiri ini muncul pada tahun 1985 dengan pencetusnya yaitu Theodore Levitte, namun kata globalisasi masih memiliki makna yang sangat luas, (Cholil, 2019).

Cholil (2019) menambahkan dalam argumennya, globalisasi telah membuat adanya perstauan dunia dalam sebuah komunitas yang dikenal sebagai“perkampungan dunia" atau global village. Perkampungan dunia dalam era itu hampir mencakup seluruh aspek kehidupan, meliputi; aspek ekonomi (economic globalization), aspek politik (politic globalization), aspek pendidikan (education globalization), aspek kebudayaan (cultural globalization), aspek keagamaan (religious globalization), aspek pengetahuan dan informasi (knowledge and information globalization). Aspek-aspek inilah yang mempengaruhi kehidupan masyarakat, baik dalam skala lokal seperti antar pribadi, keluarga, dan masyarakat. Bahkan dalam skala yang lebih luas seperti antar budaya, agama, profesi, dan bahkan antar bangsa.

Masyarakat Indonesia harus siap terhadap konsekuensi yang harus dihadapi selama arus globalisasi yang mengancam lunturnya budaya Indonesia itu sendiri. Salah satu komponen dalam masyarakat adalah masyarakat yang terpelajar. Golongan yang termasuk dalam masyarakat terpelajar terbagi menjadi dua, yakni pelajar dan pembelajar. Mozaik peradaban dalam era sekarang ini atau yang sering disandingkan dengan miniatur negara adalah kampus. Di dalam kampus, pelajar disebut sebagai mahasiswa yang memiliki tugas mencari kemudian mengkaji ilmu yang didapatkannya. Sedangkan pembelajar dikenal dengan sebutan dosen yang memiliki tugas membagikan ilmu kepada mahasiswa selama pembelajaran itu berlangsung, baik di dalam kelas maupun di luar kelas.

Mahasiswa dan dosen yang termasuk dalam komponen kampus harus memiliki pemikiran yang luas dan siap menjawab tantangan masa depan kampusnya. Arus globalisasi juga dapat mempengaruhi goyahnya kebudayaan kampus apabila komponen dalam kampus tidak peduli dengan tantangan ke depan. Kebudayaan Indonesia yang seharusnya bisa dijaga dan dirawat dengan baik dapat dengan mudah berganti menjadi budaya asing. Budaya Indonesia tidak lagi diminati oleh warganya sendiri karena warga Indonesia lebih memilih dan tertarik dengan kebudayaan. Ini merupakan masalah yang harus dikaji dengan mendalam.

Lancarnya arus globalisasi yang berhasil masuk ke dalam beberapa sektor, salah satunya adalah pendidikan, membuat komponen pendidikan harus memahami dan memiliki rencana matang untuk menjadikan tantangan menjadi peluang. Apalagi dengan hadirnya era disrupsi seperti sekarang ini. Dalam Kamus Besar Bahasa Indonesia (KBBI), disrupsi didefinisikan hal tercabut dari akarnya. Jika diartikan dalam kehidupan sehari-hari, disrupsi adalah sedang terjadi perubahan 


\section{VISA: Journal of Visions and Ideas}

\section{Vol 2 No 2 (2022) 191-201 E-ISSN 2809-2058 P-ISSN 2809-2643 \\ DOI: 47467/visa.v2i2.993}

fundamental atau mendasar, yaitu evolusi teknologi yang menyasar sebuah celah kehidupan manusia (Kasali 2018).

Salah satu akibat dari evolusi teknologi (terutama informasi) yang mengubah tatanan kehidupan di dunia ini adalah akibat dari adanya digitalisasi. Beberapa pihak bahkan berpendapat bahwa disrupsi adalah sebuah tantangan yang diawali dengan ancaman. Namun beberapa pihak pula berpendapat bahwa kondisi saat ini atau kondisi dalam era disrupsi ini adalah sebuah peluang. Beralihnya aktivitas-aktivitas yang dilakukan oleh masyarakat dari dunia nyata ke dunia maya adalah salah satu hal yang terjad dalam era disrupsi ini.

Fenomena ini terjadi dalam perkembangan pola yang mengakar dalam semua sektor, diawali dengan dunia bisnis, perbankan, transportasi, sosial masyarakat bahkan sampai mempengaruhi dunia pendidikan. Sektor pemdidikan merupakan sektor yang sakral bagi para komponen di dalamnya.

Istilah disrupsi (disruption) istilah yang dipopulerkan oleh ahli yang bernama Clayton Christensen dan Michael Porter sebagai kelanjutan dari tradisi berpikir "harus berkompetisi, untuk bisa menang "(for you to win, you've got to make somebody lose)". Kedua profesor Harvard Business School ini telah mendominasi dunia bisnis dalam 22-37 tahun terakhir. Perusahaan dari segala jenjang dan industri perlu menerapkan teknologi baru guna menciptakan model-model bisnis canggih yang mampu menghadirkan nilai yang lebih besar bagi para pelanggan mereka karena ada lawan-lawan yang tidak kelihatan yang berusaha untuk menggeser kedudukan mereka (Kasali 2018).

Instansi-instansi nya tidak begitu mempunyai power yang kuat untuk melawan. Akan tetapi, mereka mempunyai suatu nilai yang hampir dapat menyamai teknologi mereka. Seiring berkembang nya ilmu pengetahuan manusia dengan menciptakan inovasi-inovasi baru, tentu membawa parsial lapisan masyarakat seolah-olah terbang di atas awan karena seluruh kebutuhan nya hampir semua dipenuhi oleh teknologi. Era disrupsi telah menawarakan opsi untuk merekontruksi dan menginovasi. Dua-duanya bagus untuk diaplikasikan tergantung cara menemukan peluangnya sehingga dapat menghasilkan output yang bernilai.

\section{Rumusan Masalah}

1. Apa yang Anda ketahui tentang era disrupsi?

2. Bagaimana era disrupsi mempengaruhi dunia kampus?

3. Apa saja tantangan yang diterima oleh dunia kampus era disrupsi?

4. Apa saja peluang yang diterima oleh dunia kampus era disrupsi?

\section{Tujuan Penelitian}

1. Untuk mengetahui pemahaman responden tentang era disrupsi.

2. Untuk mengetahui bagaimana era disrupsi mempengaruhi dunia kampus.

3. Untuk mengetahui tantangan yang diterima oleh dunia kampus era disrupsi.

4. Untuk mengetahui peluang yang diterima oleh dunia kampus era disrupsi. 


\section{VISA: Journal of Visions and Ideas}

\section{Vol 2 No 2 (2022) 191-201 E-ISSN 2809-2058 P-ISSN 2809-2643 \\ DOI: 47467/visa.v2i2.993}

\section{Manfaat Penelitian}

1. Mengetahui era disrupsi dari berbagai perspektif, mahasiswa dan dosen.

2. Mengetahui pengaruh era disrupsi terhadap dunia kampus.

3. Mengetahui tantangan yang diterima oleh dunia kampus era disrupsi.

4. Mengetahui peluang yang diterima oleh dunia kampus era disrupsi.

\section{Objek Penelitian}

Objek dalam penelitian karya tulis ilmiah yang peneliti lakukan adalah komponen kampus. Komponen kampus tersebut terdiri atas mahasiswa dan dosen yang sudah peneliti pilih. Mahasiswa dan dosen yang peneliti pilih merupakan civitas akademika Universitas Ibn Khaldun Bogor.

\section{Batasan Masalah}

Batasan masalah dalam karya tulis ilmiah mencakup bahasan mengenai era disrupsi yang dikhususkan pada kampus Universitas Ibn Khaldun Bogor.

\section{METODE PENELITIAN}

Metode yang peneliti gunakan adalah metode kualitatif. Dalam metode kualitatif ini, peneliti melakukan wawancara kepada responden yang terdiri dari mahasiswa dan dosen terpilih di Universitas Ibn Khaldun Bogor. Setelah peneliti mendapatkan jawaban dari responden yang dilakukan dengan wawancara ini, peneliti mencantumkan semua jawaban dalam penelitian ini kemudian dijabarkan dan dijelaskan dalam bentuk paragraf.

\section{TINJAUAN LITERATUR}

Dalam studi tentang bagaimana inovasi teknologi mempengaruhi nasib tatanan kehidupan terkemuka, misalnya, inovasi radikal versus inkremental adalah awal skema kategorisasi berbasis atribut. Pernyataan dari asosiasi yang dibangun di atas skema ini adalah yang dilaksanakan oleh suatu tatanan cenderung melakukannya dengan baik ketika dihadapkan dengan inovasi tambahan tetapi mereka tersandung dalam menghadapi perubahan. Namun, tatanan kehidupan suatu kampus yang berhasil mengendalikan perubahan ini.

Untuk memperhitungkan perubahan ini, Tushman dan Anderson (1986) menawarkan perbedaan skema kategorisasi: peningkatan kompetensi versus perubahan teknologi yang merusak kompetensi. Ini skema menyelesaikan banyak banyak perubahan, tetapi peneliti selanjutnya menemukan yang baru yang skema Tushman-Anderson dilakukan penelitian selanjutnya. Terutama, Henderson dan Clark's (1990) yang mengkaji terkait perubahan ini.

Sesuatu yang menjadi sebuah gangguan atau Bahasa lainnya bisa dikatakan sebagai tantanga, pada gilirannya, adalah upaya untuk menyelesaikan perubahan yang terjadi dalam suatu tempat yang peneliti amati. Begitu pula dalam industri 


\section{VISA: Journal of Visions and Ideas}

\section{Vol 2 No 2 (2022) 191-201 E-ISSN 2809-2058 P-ISSN 2809-2643 \\ DOI: 47467/visa.v2i2.993}

disk-drive yang pernah dilakukan oleh Henderson dan Clark. Teori deskriptif sering dicirikan oleh sejumlah besar skema kategorisasi karena fenomena umumnya memiliki banyak perbedaan. Seringkali dalam fase ini, tidak ada model yang tak terbantahkan superior: Masing-masing tampaknya mampu menjelaskan perubahan itu sendiri. Kuhn (1962) mengamati bahwa kondisi yang sangat mirip menandai periode sebelum munculnya paradigma dalam berbagai bidang penyelidikan ilmiah yang sejarahnya ia catat akibat adanya suatu perubahan tersebut.

Setiap putaran lengkap di sekitar bagian dalam teori piramida terdiri dari sisi induktif dan deduktif samping. Peneliti mencatat bahwa semua bentuk pengamatan, sadar atau tidak sadar, dipengaruhi oleh pengalaman sebelumnya, atau beberapa teori yang digunakan.

Danneels (2004) mengamati bahwa model tantangan akibat perubahan hanya diturunkan dari data historis, dan dia benar: itu diturunkan secara induktif, dan data hanya ada tentang masa lalu. Danneels dan Teells, dalam pernyataan apa pun bahwa perubahan yang terjadi itu dapat didefinisikan, mereka tampaknya menyimpulkan, bahwa jika suatu masyarakat dalam sebuah tatanan kehidupan itu ketinggalan teknologi, itu mengganggu. Definisi tersebut berasal dari sejarah, tetapi definisi dari gangguan (dinyatakan kembali selanjutnya) secara independen dari hasil (Christensen dan Bower, 1996).

\section{HASIL DAN PEMBAHASAN}

Berdasarkan hasil dari wawancara yang dilakukan oleh peneliti, peneliti menemukan beberapa jawaban yang bervariasi. Dari jawaban-jawaban tersebut, peneliti menjabarkannya dengan metode deskriptif. Metode dalam menganalisis ini, peneliti menjabarkan dalam bentuk paragraf yang dideskripsikan dari setiap jawaban.

Pertanyaan pertama yang peneliti ajukan adalah mengenai apa yang responden ketahui mengenai era disrupsi. Mengingat era disrupsi merupakan era yang harus semua masyarakat Indonesia hadapi dari lapisan manapun, dari sektor manapun, atau dari bagian manapun. Peneliti menanyakan pertanyaan tersebut pada semua responden. Berikut merupakan jawaban yang diberikan oleh responden 1.

\section{Responden 1}

Era disrupsi ini adalah terjadi perubahan dalam skala besar-besaran terkait dengan inovasi dan teknologi. Era disrubsi telah merubah segala macam tatanan kehidupan sekarang semuanya serba e (elektronik). Kalau di dunia pendidikan kita terlebih adanya pandemic ini akhirnya pembelajaran kita secara online.

Berdasarkan jawaban yang diberikan oleh reponden pertama, ia memberikan keterangan cukup jelas mengenai wawasan era disrupsi yang ada 


\section{VISA: Journal of Visions and Ideas}

\section{Vol 2 No 2 (2022) 191-201 E-ISSN 2809-2058 P-ISSN 2809-2643 \\ DOI: 47467/visa.v2i2.993}

dalam dirinya. Inti dari apa yang diketahui oleh responden 1 adalah adanya perubahan besar-besaran terkait tatanan kehidupan karena berada dalam era disrupsi ini. Jawaban mengenai era disrupsi ini disampaikan pula oleh responden 2 yang intinya juga sama yaitu adanya perubahan secara signifikan. Berikut jawaban dari responden 2 .

\section{Responden 2}

Era disrupsi adalah sesuatu yang terjadi yaitu perubahan yang terjadi secara fundamental yang melingkupi beberapa aspek bahkan semua aspek kehidupan. Perubahan tersebut mampu mengubah sistem yang ada dalam tatanan kehidupan dalam berbagai bidangnya.

Jawaban responden 1 dan responden 2 tidak jauh berbeda. Beralih ke jawaban yang diberikan oleh responden 3. Responden 3 mengatakan bahwa era disrupsi ini merupakan suati momentum dimana perubahan apapun dapat terjadi dengan mudah. Berikut merupakan jawaban yang diberikan oleh responden 3.

\section{Responden 3}

Era disrupsi merupakan era dimana ini merupakan sebuah momentum yang harus dihadapi selama kehidupan ini masih berlangsung. Persaingan akan semakin banyak, apalagi era kampus.

Berdasarkan dari ketiga jawaban yang sudah diberikan oleh ketiga responden di atas, ini membuktikan bahwa semua responden mengerti dan paham mengenai apa yang dimaksud dengan era disrupsi itu sendiri.

Dilanjutkan dengan nomor pertanyaan yang kedua. Pertanyaan kedua ini menanyakan mengenai bagaimana era disrupsi berdampak pada universitasuniversitas, sekolah-sekolah, lembaga-lembaga, dan lain-lainnya. Berikut merupakan jawaban dari reponden 1 .

\section{Responden 1}

Terkait dengan perubahan teknologi yang sangat cepat tentu saja kalau dalam dunia pendidikan membutuhkan adaptasi juga terkait dengan penggunaan teknologi. Contohnya, ketika dalam perkuliahan saat ini menggunakan teknologi-teknologi. Seperti halnya mahasiswa sekarang menggunakan FRS, SIAK dan LMS dan sebagainya sehingga peran-peran manusia banyak yang dikurangi juga. Tentu pasti ada dampak negatif dan positif dari lahirnya era disrubsi ini.

Responden 1 menjawab mengenai dengan adanya era disrupsi ini sangat mempengaruhi kemajuan dunia kampus itu sendiri. Ia menjelaskan adanya kemudahan-kemudahan dalam teknologi. Selanjutnya, dengan adanya era disrupsi ini pula dapat menggantikan peran manusia karena peran manusia dialihkan dengan teknologi. Sehingga era disrupsi sangat mempengaruhi majunya suatu kampus. 


\section{VISA: Journal of Visions and Ideas}

\section{Vol 2 No 2 (2022) 191-201 E-ISSN 2809-2058 P-ISSN 2809-2643 \\ DOI: 47467/visa.v2i2.993}

Jawaban lain juga peneliti dapatkan dari responden-responden selanjutnya. Responden 2 menjawab mengenai hal yang sama dengan responden 1. Ia menjelaskan mengenai mudahnya teknologi yang dijadikan sebagai sistem untuk mengolah data dan mengatur segala sistem yang ada di dalam kampus. Berikut merupakan jawaban dari responden 2 .

\section{Responden 2}

Dengan adanya era disrupsi yang terjadi sekarang ini snagat mempengaruhi aktivitas penghuni kampus di dalamnya. Yang sebelumnya dijalankan oleh manusia saja, namun sekarang dengan canggihnya teknologi, hal tersebut telah tergantikan.

Dalam pertanyaan kedua, ada jawaban tambahan dari responden lain yaitu responden 3. Responden 3 mengatakan bahwa era disrupsi tidak hanya memengaruhi bidang pendidikan saja, namun juga semua bidang lain yang sedang dijalankan oleh masyarakat, baik secraa umum maupun khusus. Berikut merupakan jawaban dari responden 3 .

\section{Responden 3}

Era disrupsi ini tidak hanya memengaruhi sektor pendidikan saja, namun juga politik, ekonomi, dan segala sektor yang ada dalam tatanan kehidupan ini.

Pertanyaan selanjutnya adalah mengenai tantangan apa saja yang kemungkinan diterima oleh masyarakat kampus dengan adanya era disrupsi ini. Responden 1 menjawab pertanyaan dengan mengkorelasikan apa yang terjadi di dalam kampus. Berikut merupakan jawaban dari responden 1.

Ketika terjadinya era disrubsi inovasi teknologi yang masuk dan merubah kehidupan kita tentu saja tidak semuanya bisa langsung mudah menerima nya tentu dibutuhkan adaptasi. Ini juga terjadi di UIKA tidak semua langsung mudah menerima perubahan ini baik dari dosen, tenaga peendidiknya dan juga dari mahasiswa nya. Jadi kalo melihat kurva s yang pertama, ada inovatornya sekitar 2,5 persen, lalu bergeser yang menerima (adaptor) sekitar 13,5 persen lalu limajority 34 persen lalu lab majority 34 persen dan yang terakhir mengikuti 16 persen. Jadi seperti yang kita rasakan dosen sudah bisa menggunakan dengan baik LMS kita dan bukan cuma di UIKA saja kalau kita melihat di kota Bogor kata Kadis kota Bogor 90 persen pembelajaran saat ini menggunakan whatssup. Jadi ini terjadi difusi inovasi, tidak semuanya siap baik dosen maupun mahasiawa langsung bisa menyesuaikan dengan era ini, jadi ini termasuk tantangan kita sehingga kita harus selalu meningkatkan kualitas diri.

Responden 1 menjawab dengan sangat jelas. Ia menggambarkan tantangan yang dihadapi dengan teliti. Pertanyaan selanjutnya yaitu mengenai peluang yang diterima oleh masyarakat kampus ketika berada dalam era disrupsi. Berikut merupakan jawaban dari responden 1. 


\section{VISA: Journal of Visions and Ideas}

\section{Vol 2 No 2 (2022) 191-201 E-ISSN 2809-2058 P-ISSN 2809-2643 \\ DOI: 47467/visa.v2i2.993}

Dalam jawaban lain yang peneliti dapatkan, responden 2 menawab mengenai bagaimana sulitnya ketika tenaga manusia digantikan dengan teknologi ketika manusia sedang keadaan malas maka ia tidak beraktivitas. Hal tersebut menjadikan sebuah tantangan baru bagi manusia. Apalagi dalam dunia kampus, ketika masyarakat kampus yang sebelumnya memiliki aktivitas lain, namun sudah digantikan oleh teknologi dan orang tersebut merasakan kemalasan yang mengakar dalam dirinya, maka ini menjadi tantangan bagi kampus itu sendiri. Berikut merupakan jawaban dari responden 2 .

\section{Responden 2}

Ketika masyarakat di kampus harus berinovasi secara matang namun aktivitasnya digantikan oleh teknologi, maka ini menjadi tantangan tersendiri bagi kampus karena berkuranganya aktivitas yang dilakukan oleh masyarakat kampus.

Kemudian, responden lain (responden 3) mengatakan tantangannya adalah masyarakat kampus belum bisa dengan cepat memahami teknologi yang harus digunakan dalam pembelajaran maupun pengaturan sistem yang ada di dalam kampus. Berikut merupakan jawaban dari responden 3.

\section{Responden 3}

Tantangannya adalah orang-orang di kampus kadang orang tua, nah unutk mengikuti perkembangan zaman ini, kita belum bisa dengan cepat sesuai dengan prakteknya. Sedangkan kita harus mengikuti perkembangan zaman tersebut. Misalkan ada orang yang tidak dapat menggunakan teknologi, maka akan gagap dalam melaksanakan pembelajaran.

Dalam pertanyaan mengenai tantangan yang akan diterima saat era disrupsi ini, ternyata tantangan itu bervariasi. Tidak hanya dalam sektor pendidikan saja, namun merambah ke sektor lain. Dalam dunia kampuspun, tantangan-tantangan itu bermunculan seiring berkembangnya era disrupsi ini.

Pertanyaan terakhir yang peneliti ajukan adalah mengenai peluang apa saja yang bisa didapat selama memasuki era disrupsi ini. Setiap responden memiliki jawaban yang berbeda, namun pada hakikatnya, semua responden mengatakan bahwa peluang itu tetap ada dalam era disrupsi ini. Berikut merupakan hasil dari jawaban yang peneliti dapatkan setelah wawancara kepada semua responden.

\section{Responden 1}

Dalam dunia pendidikan tentu peluangnya banyak terkait pembelajaran saat ini seperti mahasiswa dapat melakukan perkuliahan secara online dari berbagai macam daerah yang mendaftarkan diri nya di Universitas Ibn Khaldun Bogor dapat melakukan atau mengikuti pembelajaran dari daerah nya masing-masing. Peluang selanjutnya kemudian misalnya bisa menghemat biaya untuk mencetak dokumen-dokumen karena sekarang semuanya telah menggunakan teknologi. 


\section{VISA: Journal of Visions and Ideas}

\section{Vol 2 No 2 (2022) 191-201 E-ISSN 2809-2058 P-ISSN 2809-2643 \\ DOI: 47467/visa.v2i2.993}

\section{Responden 2}

Semakin adanya tantangan unutk berinovasi, maka semakin besar pula peluang yang akan didapatkan. Contohnya yaitu ketika kita harus berinovasi, maka kita harus berpikir kreatif. Dengan berpikir kreatif ini, dapat memunculkan pikiran-pikiran kritis untuk menganlisa, yang biasa disebut dengan critical thinking.

\section{Responden 3}

Peluangnya adalah ketika kampus ini sudah dipandang oleh masyarakat kita atau masyarakat pada umumnya, ketika lulusan-lulusan dari SMA mengetahui bahwa adanya kebaikan dari sebuah kampus tersebut, sebagai contoh kampus UIKA, maka lulusan-lulusan tersebut akan memilih kampus UIKA yang menjadi kampus pilihannya untuk dijadikan tempat belajar.

Berdasarkan jawaban yang responden berikan dalam pertanyaan ketiga, semua responden mengatakan bahwa memang di dalam era disrupsi terdapat peluang besar yang ada dan harus dijadikan sebagai lecutan semangat untuk berinovasi ke arah yang lebih baik lagi.

\section{KESIMPULAN}

Era disrupsi merupakan era dimana terjadi perubahan yang besar dan cepat dalam tatanan kehidupan masyarakat. Era disrupsi sudah memasuki dunia kampus karena era disupsi pula tidak hanya memengaruh sektor tertentu saja, namun mempengaruhi sektor pendidikan, contohnya adalah di dalam kampus. Setelah peneliti melakukan penelitian ini, peneliti menyimpulkan bahwa era disrupsi memang sudah betul-betul masuk dalam dunia pendidikan, termasuk dalam dunia kampus. Dengan adanya era disrupsi ini, masyarakat kampus harus memahami berjalannya tatanan kehidupan yang sedang terjadi di dalamnya.

Banyak tantangan yang harus dihadapi oleh masyarakat kampus dengan hadirnya atau memasukinya era disrupsi ini. Era disrupsi sangat erat kaitannya dengan teknologi, maka akan banyak tantangan yang didapat seperti beralihnya penggunaan tenaga manusia ke teknologi dan harus dikuasainya teknologi tersebut. Namun, selain beberapa tantangan yang muncul, ada pula peluang-peluang yang nantinya ternyata dengan adanya era disrupsi dapat mempengaruhi kemajuan suatu kampus. Dengan adanya era disrupsi yang erat kaitannya dengan majunya teknologi, maka akan banyak orang yang merasa ini menjadi peluang besar bagi majunya suatu pendidikan. Contohnya adalah mudahnya sistem yang dipakai dalam pengelolaan data kampus. Selain itu, inovasi-inovasi juga bermunculan dan menjadikan masyarakat kampus menjadi masyarakat yang berpikir kritis atau yang biasa disebut dengan critical thinking.

\section{Saran}




\section{VISA: Journal of Visions and Ideas \\ Vol 2 No 2 (2022) 191-201 E-ISSN 2809-2058 P-ISSN 2809-2643 \\ DOI: 47467/visa.v2i2.993}

Dalam suatu penelitian, maka akan lebih baik jika penelitian tersebut dapat dilanjutkan lagi ataupun dikaji lagi oleh peneliti-peneliti selanjutnya dengan mempertimbangan hasil penelitian-penelitian sebelumnya. Peneliti menyarankan kepada peneliti selanjutnya untuk melakukan penelitian dengan skala yang lebih besar sehingga nanti hasil dari penelitian yang dilakukan dapat menambah kesimpulan baru. 


\title{
VISA: Journal of Visions and Ideas
}

\author{
Vol 2 No 2 (2022) 191-201 E-ISSN 2809-2058 P-ISSN 2809-2643 \\ DOI: 47467/visa.v2i2.993
}

\section{DAFTAR PUSTAKA}

Bower J.L. and Christensen, C.M. (1996). Customer Power, Strategic Investment, and the Failure of Leading Firms. Strategic Management Journal. 17(3):197218 (March).

Cholil, A. F. (2019). PENGARUH GLOBALISASI DAN ERA DISRUPSI TERHADAP PENDIDIKAN DAN NILAI-NILAI KEISLAMAN. Sukma: Jurnal Pendidikan. 3(1):117-136. https://doi.org/10.32533/03106.2019.

Danneels, E. (2004). Disruptive Technology Reconsidered: A Critique and Research Agenda. Journal of Product and Innovation Management. 21(4):246-258.

Henderson, R.M. and Clark, K.B. (1990). Architectural Innovation: The Reconfiguration of Existing Systems and the Failure of Established Firms. Administrative Science Quarterly. 35(1):9-30.

Kasali, Rhenald. 2018. The Great Shifting: Ketika Platform Berubah Kehidupan dan Bisnis pun Berpindah. Jakarta: PT. Gramedia Pustaka Utama.

Kuhn, T. (1962). The Structure of Scientific Revolutions. Chicago: University of Chicago Press.

Lestari, H., \& Hanafi, J. (2020). Persepsi Guru SD/MI Tentang Pendidikan Seks Bagi Anak di Era Revolusi 4.0. Reslaj : Religion Education Social Laa Roiba Journal, 2(1), 142-153. https://doi.org/10.47467/reslaj.v2i2.138

Norman, E., \& Aisyah, I. (2019). Bisnis Online di Era Revolusi Industri 4.0 (Tinjauan Fiqih Muamalah). Al-Kharaj : Jurnal Ekonomi, Keuangan \& Bisnis Syariah, 1(1), 30-44. https://doi.org/10.47467/alkharaj.v1i1.15

Tushman, M. and Anderson, P. (1986). Technological Discontinuities and Organizational Environments. Administrative Science Quarterly. 31:439465. 